\title{
ПРАВОВЕ ЗАБЕЗПЕЧЕННЯ ЗДІЙСНЕННЯ МІЖНАРОДНОГО БІЗНЕСУ КОНДИТЕРСЬКИХ ПІДПРИЕМСТВ
}

\section{А. В. Вітюк, А. І. Сліденко}

Вінницький національний технічний університет

Хмельницьке шосе, 95, м. Вінниця, 21000, Україна. E-mail: anna_vitiuk@ukr.net

Досліджено проблеми правового забезпечення здійснення міжнародного бізнесу кондитерськими підприємствами. Розглянуто основні інституційні зміни, що відбулися в країні за останні роки, які мали прямий вплив на міжнародний бізнес кондитерських підприємств: вступ до Світової організації торгівлі та підписання Угоди про асоціацію України з Свропейським Союзом. Встановлено значні обсяги експорту української продукції на закордонні ринки та чинники впливу на їх зміну. Встановлено основні завдання для активізації міжнародного бізнесу кондитерських підприємств. Розділено правове забезпечення міжнародного бізнесу в залежності від рівня його здійснення - на рівні підприємств запропоновано розглядати розробку і створення нормативних документів на рівні самих підприємств; на рівні галузі - готувати галузеві програми розвитку, а на державному рівні впроваджувати та узгоджувати міжнародні стандарти та норми. У статті досліджено основні нормативні документи, що впливають на діяльність підприємств та стандарти якості якими підприємствами повинні використовувати. На рівні галузі проаналізовано основні закони та нормативні документи, що регламентують діяльність кондитерських підприємств та встановлено спрямованість цих законів на забезпечення виробництва високоякісної продукції. На рівні держави через аналіз показників експорту та імпорту доведено необхідність гармонізації українського правового забезпечення до вимог країн-покупців продукції. Проаналізовано обсяги експорту та імпорту кондитерських виробів в залежності від участі України в різних економічних об'єднаннях. Встановлено, що негативний економічний ефект від участі України в різних економічних об'єднаннях пояснюється низькою конкурентоспроможністю українських виробників на міжнародних ринках. Розкрито зміст нормативних актів, що мали позитивний вплив на розвиток міжнародного бізнесу кондитерських підприємств.

Ключові слова: правове забезпечення, кондитерське підприємство, міжнародний бізнес, закон, експорт, імпорт, Світова організація торгівлі, гармонізація.

\section{ПРАВОВОЕ ОБЕСПЕЧЕНИЕ МЕЖДУНАРОДНОГО БИЗНЕСА КОНДИТЕРСКИХ ПРЕДПРИЯТИЙ}

\section{А. В. Витюк, А. И. Слиденко}

Винницкий национальный технический университет

Хмельницкое шоссе, 95, г.Винница, 21000, Украина. E-mail: anna_vitiuk@ukr.net

Исследованы проблемы правового обеспечения осуществления международного бизнеса кондитерскими предприятиями. Рассмотрены основные институциональные изменения, произошедшие в стране за последние годы, которые имели прямое влияние на международный бизнес кондитерских предприятий - вступление в ВТО и подписание Соглашения об ассоциации Украины с Европейским Союзом. Установлены значительные объемы экспорта украинской продукции на зарубежные рынки и причины влияния на их изменение. Установлены основные задании перед государством для активизации международного бизнеса кондитерских предприятий. Разделены правовое обеспечение международного бизнеса в зависимости от уровня его осуществления на уровне предприятий предложено рассматривать разработку и создание нормативных документов на уровне самих предприятий; на уровне отрасли - готовить отраслевые программы развития, а на государственном уровне - внедрять и согласовывать международные стандарты и нормы. В статье исследованы основные нормативные документы, влияющие на деятельность предприятий и стандарты качества которыми они пользуются. На уровне области проанализированы основные законы и нормативные документы, регламентирующие деятельность кондитерских предприятий и установлено направленность этих законов на обеспечение производства высококачественной продукции. На уровне государства через анализ показателей экспорта и импорта доказана необходимость гармонизации украинского правового обеспечения требованиям стран-покупателей продукции. Проанализированы объемы экспорта и импорта кондитерских изделий в зависимости от участия Украины в различных экономических объединениях. Установлено, что отрицательный экономический эффект от Украины в разных экономических объединениях объясняется низкой конкурентоспособностью украинских производителей на международных рынках. Раскрыто содержание нормативных актов, которыеположительно повлияли на развитие международного бизнеса кондитерских предприятий.

Ключевые слова: правовое обеспечение, кондитерское предприятие, международный бизнес, закон, экспорт, импорт, Всемирная торговая организация, гармонизация.

АКТУАЛЬНІСТЬ РОБОТИ. Кондитерська галузь - одна 3 найбільш розвинених галузей харчової промисловості України. Основним напрямком розвитку цієї галузі $є$ необхідність значного зростання якості, біологічної цінності і смакових переваг продуктів харчування, що дозволить завойовувати не лише внутрішні, але й зовнішні ринки. Українські виробники успішно вийшли на світовий ринок та посідають пріоритетні місця серед інших перспективних країн, тому важливого значення набуває дослідження нормативних умов здійснення торгівлі на міжнародному ринку (табл. 1). 
Таблиця 1 - Світовий рейтинг виробників кондитерських виробів за 2017 р.

\begin{tabular}{|l|c|c|c|}
\hline \multicolumn{1}{|c|}{ Назва фірми } & $\begin{array}{c}\text { Чистий обсяг } \\
\text { продажів (млн. дол.) }\end{array}$ & Кількість працівників & Кількість фабрик \\
\hline 1. Mars Inc (США) & 18000 & 3400 & 52 \\
\hline 2. Mondelez International (США) & 12900 & 100000 & 156 \\
\hline 3. Ferrero Group (Iталія) & 10637 & 33245 & 22 \\
\hline 24. Roshen Confectionery Corp. & 800 & 10000 & 8 \\
\hline 43. Konti Group & 469 & 3792 & 3 \\
\hline 67. AVK Confectionery & 275 & 3500 & 5 \\
\hline
\end{tabular}

Особливо актуальними $є$ ці питання з огляду на провідні місця українських підприємств на світовому рейтингу виробників кондитерської галузі.

Розвитку різних аспектів правового забезпечення здійснення міжнародного бізнесу кондитерськими підприємствами України присвячені наукові праці багатьох сучасних учених, зокрема Журавель А. В., Артюх Т. М., Олефір А. О., Чубик А., Ус І., Вдовенко Ю., Пахаренко О. В. та інших. Особливо важливим $\epsilon$ робота закордонних науковців, таких як С. Злоткін, Дж. Сікмен, А. Лерті, Ж. Йонг, громадських організацій та державних органів над налагодженням співпраці з українськими кондитерськими підприємствами, що знайшли своє відображення в численних наукових працях на нормативноправових актах [1]. Проте розвиток швидких інтеграційних процесів, удосконалення технологій та зростання вимог та якості продукції вимагають постійної роботи над формуванням таких нормативноправових умов діяльності та їх правового забезпечення, що з одного боку сприяли б активному розвитку підприємств, а з іншого - забезпечували споживача високоякісною продукцією.

Метою статті є дослідження змісту трансформацій правового забезпечення здійснення міжнародного бізнесу кондитерськими підприємствами.

МАТЕРІАЛ I РЕЗУЛЬТАТИ ДОСЛІДЖЕНЬ. Формування правового забезпечення торгівлі кондитерських підприємств $\epsilon$ достатньо широким та динамічним процесом. Основними причинами такого стану є, з одного боку, зростаючі обсяги діяльності кондитерських підприємств, та відповідно їх важливість в країні та постійна інтеграція України до різного роду об'єднань - з іншого. Певними особливостями у юридичному регулюванні характеризується і сама кондитерська промисловість, на яку опосередковано впливає нормативно-правове регулювання цукрової, молокопереробної та сільськогосподарської галузей, які є постачальниками основної сировини для кондитерського виробництва. Накладання значних внутрішніх умов виробництва та бажання розвивати міжнародний бізнес формують перед державою ряд завдань щодо правового регулювання міжнародного бізнесу кондитерських підприємств полягають у:

1. Розробці та прийнятті законів, що забезпечує правову основу i захист інтересів кондитерських підприємств.
2. Реалізації державної політики щодо розвитку роздрібної та оптової торгівлі кондитерськими виробами за кордоном, а також послаблення прямих форм втручання i бюрократичного контролю за діяльністю кондитерських підприємств.

3. Створення умов для вільної добросовісної конкуренції на товарних ринках, вільного просування товарів на міжнародному ринку.

4. Сприяння формуванню та товарному насиченню міжнародного ринку кондитерською продукцією поліпшеної якості з урахуванням попиту населення.

5. Зняття обмежень адміністративного регулювання міжнародної торгівлі кондитерськими виробами.

6. Підвищення темпів зростання товарообороту на основі політики стимулювання розвитку споживчого сектору.

Ефективна реалізація зазначених напрямів державного регулювання повинна базуватися на комплексі заходів щодо зменшення прямого впливу на розвиток галузі кондитерського виробництва (включаючи адміністративні заходи: заборони, дозволи, примус) та посилення ролі непрямих державних регуляторів, які складаються з проведення ефективної цінової, фінансової, грошово-кредитної, амортизаційної та зовнішньоекономічної політики, а також широкого впровадження інституційних регуляторів (правових, етичних, психологічних, організаційних та спеціальних норм).

3 огляду на такі повномасштабні завдання вважаємо за доцільне розділити правове забезпечення здійснення міжнародного бізнесу на певні заходи в залежності від рівня їх здійснення:

1. Розробка і створення нормативних документів на рівні самих підприємств.

2. Підготовка галузевих програм розвитку на рівні міністерств та відомств.

3. Імплементація та узгодження міжнародних стандартів та норм.

Розглянемо більш детально кожен із запропонованих заходів та способи їх реалізації в державі.

1. Розробка і створення нормативних документів на рівні самих підприємств.

Варто відзначити, що основним нормативноправовим документом, що здійснює регулювання господарської діяльності в країні, в т.ч. і кондитерської галузі, є Господарський кодекс України. Від- 
повідно нього формування зовнішньоекономічної політики, до якої належить ведення міжнародного бізнесу, спрямованої на регулювання державою відносин суб'єктів господарювання 3 іноземними суб'єктами господарювання та захист національного ринку і вітчизняного товаровиробника є пріоритетною формою держаної політики.

Проте, головним нормативно-правовим актом, що регулює міжнародний бізнес $є$ Закон України від 16 квітня 1991 р. «Про зовнішньоекономічну діяльність» № 2672-VIII від 17.01.2019 р. зі змінами та доповненнями, в якому визначаються принципи зовнішньоекономічної діяльності, окреслюється коло їі суб'єктів, визначаються види зовнішньоекономічної діяльності, закріплюються основи їі регулювання, а також передбачається встановлення спеціальних правових режимів зовнішньоекономічної діяльності й містяться норми щодо відповідальності учасників зовнішньоекономічної діяльності та захисту їх прав та інтересів [2].

Окресливши значну роль українських підприємств на світовому ринку кондитерських виробів відзначимо, що усі вони, зокрема Кондитерська корпорація «Рошен», Виробниче об'єднання «КОНTI», Кондитерська компанія «АВК» та інші менш відомі виробники здійснюють своє виробництво у відповідності до інтегрованої система менеджменту якості відповідно до вимог міжнародних стандартів: ISO 9001: 2008 та системи менеджменту харчової безпеки відповідно до вимог IFS Food. Більше того зазначені підприємства виступають ініціаторами громадської сертифікації, що носить здебільшого маркетингові рекламні цілі.

2. Підготовка галузевих програм розвитку на рівні міністерств та відомств

Особливо важливого значення у правовому полі регулювання діяльності кондитерських підприємств в Україні надано питанням якості. Основним нормативно - правовим актом у сфері якості кондитерської продукції $є$ Закон України «Про безпечність та якість харчових продуктів». Цей закон регулює відносини між органами виконавчої влади, виробниками, продавцями (постачальниками) та споживачами продуктів кондитерської галузі. Відповідно до нього визначено правовий порядок забезпечення безпечності та якості продуктів, що виробляються, знаходяться в обігу, імпортуються, експортуються. Також діє спеціальне законодавство України щодо окремих категорій харчових продуктів, зокрема Закон України «Про молоко та молочні продукти», «Про дитяче харчування» тощо, яке повинне відповідати положенням Закону України «Про безпечність та якість харчових продуктів» [3].

Однак, головна проблема кондитерської галузі України - відсутність ефективної системи забезпечення безпеки продуктів, яка б контролювала продукт від постачальника сировини до місця продажу готового продукту. В Україні за безпечність кондитерських продуктів несуть відповідальність чотири органи: Міністерство охорони здоров'я України, Міністерство аграрної політики i продовольства України, Міністерство економічного розвитку та Міністерство природи, жоден з яких не гарантує безпечності продукту загалом, оскільки контролюють лише деякі ділянки виробництва. 3 огляду на розвиток суспільства «старий» підхід щодо безпеки харчових продуктів не виправдовує себе, оскільки базується на державному контролі відповідальності, а також на обстеженні кінцевої продукції. Так склалося, що на сьогодні в кондитерській галузі України нині діє 34 основних нормативних документи, в тому числі 23 - на готову продукцію та 11 - на напівфабрикати.

В результаті підписання 21 березня 2014 року політичних положень Угоди про асоціацію між Україною та СС, перед Україною постало завдання гармонізувати діючі стандарти 3 вимогами $€ C$, а також СОТ. Тому в державі активно ведеться робота щодо створення в кондитерській промисловості українських національних стандартів, яку, головним чином, покладено на ПАТ «Укркондитер» і низки галузевих інститутів Міністерства аграрної політики України. Ці роботи проводяться переважно за рахунок коштів підприємств. Зокрема, на сьогодні вже розроблено національні стандарти на готову продукцію - карамель, шоколад, вафлі, печиво та крекер. Підготовлено та затверджено національний стандарт на цукерки [4]. Загалом оцінювання вимог щодо кондитерських виробів здійснюється на основі 15 національних стандартів. На сьогодні активно відбувається гармонізація національних стандартів на кондитерську продукцію 3 міжнародними: разом iз наказом ДП «УкрНДНЦ» «Про прийняття нормативних документів України, гармонізованих 3 міжнародними та європейськими нормативними документами, національних стандартів України, скасування нормативних документів України та міждержавних стандартів України» [5].

Таким чином, відзначимо що основним напрямом регулювання міжнародного бізнесу кондитерських підприємств полягає у необхідності забезпечення високої якості продукції. Необхідно відзначити, що якість продуктів харчування в Україні регулюється Закон України «Про безпечність та якість харчових продуктів», який передбачає:

1. Використання системи управління безпекою харчових продуктів НАССР («Hazard Analysis and Critical Control Point»).

2. Створення Державної служби України з питань безпечності харчових продуктів та захисту споживачів, внаслідок чого Державна ветеринарна та фітосанітарнаслужба, Державна інспекція 3 питань захисту прав споживачів і Державна санітарно-епідеміологічна служба припиняють свою діяльність.

3. Впровадження принципів реєстрації ГМО джерел, а не продуктів, вироблених з них.

4. Скасування дозвільних документів та процедур, які відсутні в СС (зокрема, вимоги проведення санітарно-епідеміологічної та ветеринарно-санітарної експертизи).

Отже, розрізненість центрів відповідальності за управління галуззю все ж передбачає спільну направленість зусиль різних міністерств на забезпечення належної якості продукції.

3. Імплементація та узгодження міжнародних стандартів та норм. 
Наразі Україна знаходиться в стані активної інтеграції в світове співтовариство, що поряд із прийняттям декларативних принципів передбачає імплементацію ряду нормативно-правових положень, що діють в рамках організацій, що впливають на здійснення міжнародного бізнесу в державі та до яких Україна приєдналася. Серед них варто відзначити такі організації як Всесвітня продовольча програма, Комісія $\mathrm{OOH} 3$ права міжнародної торгівлі (ЮНСІТРАЛ), Комітет з економічних, соціальних та культурних прав, Конференція ООН з питань торгівлі та розвитку (ЮНКТАД), Європейська економічна комісія (СЕК $\mathrm{OOH})$ - (Комітет 3 питань економічного співробітництва та інтеграції (КЕСI), Комітет $з$ торгівлі), Багатосторонне агентство з питань гарантій інвестицій (БАГI), Продовольча та сільськогосподарська організація ООН (ФАО), Всесвітня митна організація, Робоча група ГУАМ з питань економіки та торгівлі, Світова організація торгівлі (СОT); Робоча група 3 питань розвитку малого і середнього бізнесу та підприємництва Організації економічного співробітництва та розвитку та ін. [6]. Множина зазначених інституцій формують масиви суперечливих та однобічних нормативно-правових актів, що подекуди перешкоджають активній міжнародній торгівлі українською продукцією, зокрема кондитерськими виробами. Втім, участь у таких об'єднаннях дозволяє поставляти українську продукцію до нових країн та збільшувати продажі у країнах, які активно імпортують українські солодощі.

Україна приєдналася до низки секторальних «нульових» домовленостей про зниження ставок на кондитерські вироби, поряд із митним і технічним регулюванням, санітарними й фітосанітарними заходами, пов'язаними 3 торгівлею кондитерською продукцією [7].

Одним із найважливіших кроків у напрямі активізації міжнародного бізнесу кондитерських підпри-

Таблиця 2 - Товарна структура зовнішньої торгівлі кондитерськими виробами

\begin{tabular}{|c|c|c|c|c|c|c|c|c|c|c|c|}
\hline & & & \multirow{3}{*}{ Роки } & \multicolumn{4}{|c|}{ Експорт } & \multicolumn{4}{|c|}{ Імпорт } \\
\hline & & & & \multicolumn{2}{|c|}{$\begin{array}{c}\text { цукор і } \\
\text { кондтерські } \\
\text { вироби } 3 \text { цукру }\end{array}$} & \multicolumn{2}{|c|}{$\begin{array}{c}\text { какао та } \\
\text { продукти } 3 \\
\text { нього }\end{array}$} & \multicolumn{2}{|c|}{$\begin{array}{c}\text { цукор і конд- } \\
\text { терські вироби } \\
3 \text { цукру }\end{array}$} & \multicolumn{2}{|c|}{$\begin{array}{c}\text { какао та } \\
\text { продукти } 3 \text { нього }\end{array}$} \\
\hline & & & & $\begin{array}{c}\text { тис. } \\
\text { дол. } \\
\text { США } \\
\end{array}$ & $\%$ & $\begin{array}{c}\text { тис. } \\
\text { дол. } \\
\text { США } \\
\end{array}$ & $\%$ & $\begin{array}{c}\text { тис. } \\
\text { дол. } \\
\text { США } \\
\end{array}$ & $\%$ & $\begin{array}{c}\text { тис. } \\
\text { дол. США }\end{array}$ & $\%$ \\
\hline & & \multirow{17}{*}{$\begin{array}{c}\text { Функціону- } \\
\text { вання в рамках } \\
\text { національного } \\
\text { законодавства }\end{array}$} & 2001 & 85942,8 & 0,5 & 100142,2 & 0,6 & 132661,7 & 0,8 & 77705,8 & 0,5 \\
\hline & & & 2002 & 112225,3 & 0,6 & 120118,6 & 0,7 & 98495,6 & 0,6 & 88495,5 & 0,5 \\
\hline & & & 2003 & 199163,8 & 0,9 & 158401,6 & 0,7 & 338847,8 & 1,5 & 109899,7 & 0,5 \\
\hline & \multirow{14}{*}{$\begin{array}{c}\text { Членство в } \\
\text { Світовій } \\
\text { організації } \\
\text { торгівлі }\end{array}$} & & 2004 & 119636,2 & 0,4 & 203289,5 & 0,6 & 103481,1 & 0,4 & 145798,4 & 0,5 \\
\hline & & & 2005 & 110201,2 & 0,3 & 239540,5 & 0,7 & 78983,70 & 0,2 & 226914,30 & 0,6 \\
\hline & & & 2006 & 113497,2 & 0,3 & 259893,4 & 0,7 & 30054,3 & 0,1 & 222904,7 & 0,5 \\
\hline & & & 2007 & 155669,2 & 0,3 & 351647,6 & 0,7 & 32723,3 & 0,1 & 268452,8 & 0,4 \\
\hline & & & 2008 & 164352,9 & 0,2 & 503124,0 & 0,8 & 67209,2 & 0,1 & 359020,0 & 0,4 \\
\hline & & & 2009 & 165184,6 & 0,4 & 448559,9 & 1,1 & 87551,1 & 0,2 & 302339,1 & 0,7 \\
\hline & & & 2010 & 206502,6 & 0,4 & 591611,9 & 1,2 & 231355,6 & 0,4 & 407333,7 & 0,7 \\
\hline & & & 2011 & 241879,3 & 0,4 & 675726,5 & 1,0 & 230705,3 & 0,3 & 491785,5 & 0,3 \\
\hline & & & 2012 & 341218,3 & 0,5 & 662341,4 & 1,0 & 83496,1 & 0,1 & 449593,2 & 0,5 \\
\hline & & & 2013 & 358837,3 & 0,4 & 556813,3 & 0,9 & 460743,2 & 0,6 & 215823,9 & 0,3 \\
\hline \multirow{4}{*}{$\begin{array}{c}\text { Після підпи- } \\
\text { сання Угоди } \\
\text { про асоціацію } \\
\text { України } 3 \\
\text { Свропейським } \\
\text { Союзом }\end{array}$} & & & 2014 & 147092,9 & 0,3 & 322877,6 & 0,6 & 59328,3 & 0,1 & 358837,3 & 0,7 \\
\hline & & & 2015 & 169508,2 & 0,4 & 187263,1 & 0,5 & 34792,8 & 0,1 & 193530,8 & 0,5 \\
\hline & & & 2016 & 352008,4 & 1,0 & 162209,1 & 0,4 & 56190,7 & 0,1 & 217083,1 & 0,6 \\
\hline & & & 2017 & 417349,4 & 1,0 & 183736,2 & 0,4 & 47591,0 & 0,1 & 236206,4 & 0,5 \\
\hline
\end{tabular}
правової точки зору система Світової організації торгівлі є своєрідним багатостороннім контрактом (пакетом угод), правилами і нормами якого регулюється більшість усієї світової торгівлі товарами та послугам [8]. На сьогодні СОТ - єдина міжнародна організація, яка встановлює глобальні правила торгівлі. На 164 іiі члени припадає понад 98\% світової торгівлі. Це дієвий майданчик для обговорення позицій і розбіжностей з багатьох торговельних питань, враховуючи баланс економічних інтересів країн-учасниць. Членство в організації значно підсилює можливість впливати на формування сучасних правил торгівлі на світовому рівні [9].

Не менш важливим кроком у сфері інтеграції української кондитерської промисловості до міжнародного ринку була ратифікація Україною Угоди про Асоціацію Україна-Свропейський Союз 16 вересня 2014 р., відповідно до якої проводиться активна гармонізація українського законодавства, що регулює кондитерську промисловість, до законодавства СС як в окремих сферах (маркування, митне регулювання, фітосанітарні заходи, стандартизація, державні закупівлі, антимонопольне регулювання та ін.), так і по відношенню до окремих категорій продуктів. Очікується, що якісна гармонізація українського законодавства 3 європейським відкриє для українських виробників широкі можливості диверсифікації експорту продукції на міжнародний ринок, а також забезпечить можливість участі в державних закупівлях в СС.

Отже, з огляду на низку представлених заходів правового забезпечення міжнародного бізнесу кондитерських підприємств доцільно дослідити їх результати на обсяги міжнародної товарної торгівлі кондитерськими виробами [10] (табл. 2). ємств був вступ до Світової Організації торгівлі. 3 
Аналіз експорту кондитерських виробів за 20012017 роки засвідчив стабільне зростання, окрім значень 2014-2015 років, коли відбулося закриття ринків збуту в Російській Феферації, яка була лідером із закупівель українських кондитерських виробів. Дослідження правового забезпечення міжнародного бізнесу засвідчило:

1. Внаслідок вступу України до Світової організації торгівлі обсяги продажу на експорт скоротилися, що свідчить про неготовність та нездатність українських виробників конкурувати на світових ринках. В той же час імпорт незначно зріс, що знову $€$ підтверджує слабкість українських виробників.

2. Підписання Угоди про асоціацію України 3 Європейським Союзом мало навпаки більш позитивний результат, що проявився у незначному зростанні експорту кондитерських виробів та певному зменшенні імпорту.

Знаковим моментом у правовому регулюванні міжнародного бізнесу кондитерських підприємств було прийняття Закону України «Про забезпечення масштабної експансії експорту товарів (робіт, послуг) українського походження шляхом страхування, гарантування та здешевлення кредитування експорту», адже саме після його прийняття експорт української цукру і кондитерських виробів з цукру у 20162017 роках зріс (1,0\% у 2016-2017 рр.) у структурі зовнішнього торгівлі вперше з 2001 року, а імпорт знизився до рекордно низького значення $(0,1 \%$ у 2016-2017 pp.).

3 огляду на такі практичні макроекономічні показники можна зробити висновок про дієвість засад державної підтримки експортної діяльності шляхом страхування, перестрахування, гарантування, часткової компенсації відсоткової ставки за експортними кредитами 3 метою створення умов для здійснення масштабної експансії експорту товарів (робіт, послуг) українського походження на зовнішні ринки, забезпечення захисту українських експортерів від ризиків неплатежів та фінансових втрат і підвищення конкурентоспроможності українських виробників на світових ринках.

Отже, матеріали аналізу засвідчили, що правове забезпечення міжнародного бізнесу кондитерських підприємств знаходиться на етапі формування, відбувається його поступове вдосконалення.Саме тому наразі Україна стоїть на порозі кардинальних змін у сфері регулювання кондитерської галузі, що пояснюється значними відмінностями між законодавством України та країн до яких ведеться експорт кондитерської продукції. Для прикладу лише в Свропейському Союзі питання безпеки та якості продуктів кондитерської галузі регулюється близько 160 європейськими директивами, які необхідно запровадити в законодавство України для створення аналогічної системи.

Відзначимо, що існує і багато спільного у діяльності вітчизняних та європейських кондитерських підприємств, зокрема забезпечення того, щоб на ринок попадали тільки безпечні для здоров'я людини продукти.

Відповідно головними цілями правового забезпечення постачання в СС української кондитерської продукції $€$ :
1. Захист інтересів споживача - недопущення шахрайства і обману, підробки, надання неправдивої інформації.

2. Забезпечення потреб споживача через надання повної інформації про продукт, щоб споживач міг правильно підібрати їжу відповідно до особливостей організму [11].

Важливе значення в правовому регулюванні міжнародного бізнесу кондитерських підприємств має дотримання положень кодексу Аліментаріус [12], який містить положення та вимоги щодо гігієни харчових продуктів, харчових добавок, а також рекомендації, яких має дотримуватися міжнародна спільнота для захисту здоров'я споживачів і забезпечення однакових торговельних методів у вигляді правил, норм, настанов та інших документів [13]. Втім, за європейськими нормами, виробникам забороняється додавати в кондитерські вироби ароматизатори, які є шкідливими для організму, але дозволяється додавання деяких видів рослинних олій за умови інформування споживачів про них добавки на упаковці виробу. Відповідно, зазначені положення суперечать один одному, що може слугувати за певних обставин перешкодою до експорту української кондитерської продукції за кордон, хоча імплементація європейських стандартів мала б сприяти підвищенню якості українського продукту.

Таким чином, спостерігається ситуація за якої продукція, якої потребують закордонні споживачі, експортуватиметься легко, а вивіз української продукції для освоєння нових закордонних ринків із місцевими виробниками буде ускладнений, що свідчить про певну негласну політику протекціонізму Європейського Союзу.

Проаналізувавши юридичні умови ведення міжнародного бізнесу кондитерськими підприємствами можна зробити висновок, що не дивлячись на складну економічну ситуацію в Україні держава та підприємці роблять все можливе, щоб утримати статус виробників високоякісного продукту. Оскільки Україна не є країною-членом ЄС, то законодавство не гармонізоване та має багато інших вимог до кондитерської галузі. Українські підходи до законодавчого регулювання інші - мають вертикальний характер, а в Свропі законодавство має горизонтальний характер - $є$ загальні вимоги до якості харчових продуктів і спеціалізовані вимоги відповідно до специфіки галузі, тому їх гармонізація виступає основою для розвитку кондитерської промисловості в Україні.

Досягнути таких результатів вдалося шляхом використання таких загальнонаукових методів наукових досліджень: аналіз і синтез - для вивчення стану та обсягів охоплення правовим забезпеченням діяльності кондитерських підприємств; історичний для дослідження трансформації вітчизняного правового забезпечення міжнародного бізнесу кондитерських підприємств та для опису закономірностей його розвитку у хронологічній послідовності; групування - для виявлення обсягів експортноімпортної діяльності кондитерських підприємств у зв'язку із вступом до різних міжнародних організа- 
цій; порівняння - для зіставлення фактичних даних торгівлі кондитерською продукцією та ін.

ВИСНОВКИ. В результаті дослідження змісту правового забезпечення здійснення міжнародного бізнесу кондитерськими підприємствами встановлено його різнонаправленість. Наслідком дослідження $€$ встановлення ряду положень наукової новизни, зокрема:

1. Доведено зростання обсягів правового регулювання бізнесу кондитерських підприємств в напрямі посилення вимог до безпеки продукції.

2. Обгрунтовано дієвість заходів державної підтримки експортної діяльності шляхом страхування, перестрахування, гарантування та часткової компенсації за експортними кредитами.

Для забезпечення подальшого зростання продажів кондитерських підприємств на міжнародному рівні зміни в правовому забезпеченні мають відбуватися на трьох рівнях на рівні підприємств, на рівні галузі та на рівні держави в основі яких має лежати гармонізація українського правового забезпечення кондитерської галузі із правовим забезпеченням країн-експортерів кондитерських виробів.

Перспективним напрямом для подальших досліджень $є$ встановлення видів та обсягів кондитерської продукції для іiї експорту за іiї можливої диверсифікації.

\section{ЛІТЕРАТУРА}

1. Рыжакова А. В., Бабина О. А. Мировой рынок кондитерских изделий. Вестник Российского государственного торгово-экономического университета. Москва. 2017. №4 (12). С. 59-74.

2. Журавель А. В. Особливості правового регулювання зовнішньоекономічної діяльності в Україні. Південноукраӥнський правничий часопис. Одеса. 2014. № 3. C. 85-89.

3. Харчова промисловість в Україні: засади правового регулювання в Україні. К. : Arzinger, 2014. $246 \mathrm{c}$.
4. Association agreement. Official Journal of the European Union. Brussel. 29.5.2014. - L 161-4- L 1612137.

5. Артюх Т. М. Аналіз системи технічного регулювання кондитерської галузі в Україні. Науковий вісник Ужгородського національного університету. Ужгород. 2016. № 7. С.32-35.

6. Порядок участі центральних органів виконавчої влади у діяльності міжнародних організацій, членом яких є Україна. Постанова Кабінету Міністрів України від 13 вересня 2002 р. №1371. С.2.

7. Олефір А. О. Національна інноваційна політика в умовах лібералізації зовнішньої торгівлі. Актуальні проблеми держави і права. 2014. Вип. 74. C. 233-245.

8. Українська призма: співпраця України з міжнародними організаціями: [авт. кол. : Чубик А., Ус І., Вдовенко Ю. та ін.]. - К. : Фонд ім. Фрідріха Еберта. Представництво в Україні, 2014. 76 с.

9. Сущенко О. А. Управління взаємодією суб'єктів експортної діяльності підприємства. Bicник КрНУ імені Михайла Остроградського. Кременчук 2016. № 1. С. 129-133.

10. Товарна структура зовнішньої торгівлі URL: http://www.ukrstat.gov.ua/ (дата звернення: 23.12.2018)

11. Пахаренко О. В. Порівняльна характеристика стандартизованих методів визначення показників якості харчових продуктів в Україні та ЄС. Економічний форум. Луцьк. 2015. № 3. С. 231-237.

12. Codex Alimentarius Commission : Guidelines on formulated supplementary foods for older infants and young children. Twenty-third edition. In., vol. CAC/GL 08-1991; Rome, 2015.

13. St. Zlotkin, J. Siekmann, A. Lartey, Yang Zh. The role of the Codex Alimentarius process in support of new products to enhance the nutritional health of infants and young children. Food and Nutrition Bulletin. Massachusetts. 2010. Vol. 31. No. 2. pp. 129-133.

\section{LEGAL SUPPORT FOR INTERNATIONAL BUSINESS OF CONFECTIONERY ENTERPRISES}

\section{A. Vitiuk, A. Slidenko}

Vinnysia National Technical University

Khmelnytske shose, 95, Vinnytsia, Ukraine, 21021.E-mail: anna_vitiuk@ukr.net

Purpose. The article aims to research the internal and external legal support of international business for Ukrainian confectionery enterprises in connection with the accession of Ukraine to international economic associations. Methodology. The main institutional changes that have taken place in the country in recent years which had a direct impact on the international business of confectionery enterprises which are the accession to the World Trade Organization and the signing of the Association Agreement between Ukraine and the European Union were considered. Significant volumes of export of Ukrainian products to foreign markets are established and the reasons of influence on their change are determined. The main tasks of the state for activating the international business of confectionery enterprises are established. The legal support of international business is divided depending on the level of its implementation - at the level of enterprises it is suggested to consider the development and creation of normative documents at the level of these enterprises; at the industry level - to prepare sectoral development programs, and at the state level - to implement and harmonize international standards and norms. The main normative documents that affect the activities of enterprises and the quality standards they serve are studied in the paper. At the industry level, the basic laws and regulations that manage the activity of confectionery enterprises are analyzed and the direction of these laws is set to ensure the production of high-quality products. At the state level, through the analysis of export and import indicators, the necessity of harmonization of Ukrainian legal provision with the requirements of the countries-buyers of products has been proved. The volume of export and import of confectionery products is analyzed, depending on the participation of Ukraine in various economic associations. It is established that the negative economic effect of Ukraine's participation 
in various economic associations is explained by the low competitiveness of Ukrainian producers in international markets. Results. It was established that for activation of international business of confectionery enterprises it is necessary to modernize the Ukrainian legal support of international business in accordance with world requirements, requirements of business partners and consumer's requirements of products in relation to the improvement of product quality. Originality. The high level of influence of Ukraine's accession to international economic organizations, which has a negative impact on the development of international business of confectionery enterprises of Ukraine has been established. Practical value. It is proved that the growth of the confectionery industry may be due to increased sales in foreign markets.

Key words: legal support, confectionery enterprise, international business, law, export, import, World Trade Organization, harmonization.

\section{REFERENCES:}

1. Ryizhakova, A. V., Babina, O. A. (2017), "The world market of confectionery products“, Vestnik Rossiyskogo gosudarstvennogo torgovo-ekonomicheskogo universiteta, Vol. 4 (12), pp. 59-74.

2. Zhuravel, A. V. (2014), "Features of legal regulation of foreign economic activity in Ukraine". Pivdennoukrainskyi pravnychyi chasopys, Vol. 3, pp. 85-89.

3. The food industry in Ukraine: the principles of legal regulation in Ukraine (2014), Arzinger, Kyiv, Ukraine.

4. Association agreement, (2014), Official Journal of the European Union, pp. 29.5.2014, pp. 161-4- L 161-2137.

5. Artiukh, T. M. (2016), "Analysis of the system of technical regulation of the confectionery industry in Ukraine", Naukovyi visnyk Uzhhorodskoho natsionalnoho universytetu, Vol. 7, pp. 32-35.

6. The procedure for the participation of central executive authorities in the activities of international organizations, of which Ukraine is a member. Resolution of the Cabinet of Ministers of Ukraine dated September 13, 2002 № 1371. Pp. 2.

7. Olefir, A. O. (2014), "National innovation policy in the conditions of liberalization of foreign trade",
Aktualni problemy derzhavy i prava, Vol. 74, pp. 233245.

8. Chubyk, A., Us, I., Vdovenko, Yu. (2014), Ukrainian prism: Ukraine's cooperation with international organizations, Kyiv, Fund after Friedrich Ebert. Representation in Ukraine, p. 76.

9. Sushchenko, O. A. (2016), Management of the interaction of export business entities, Transactions of Kremenchuk Mykhailo Ostrohradskyi National University, Vol. 1, pp. 129-133.

10. Commodity structure of foreign trade [online], Available at: <http://www.ukrstat.gov.ua/ [Accessed 23 December 2018].

11. Pakharenko, O. V. (2015), Comparative characteristics of standardized methods for determining food quality indicators in Ukraine and the EU, Ekonomichnyi forum, Vol. 3, pp. 231-237.

12. Codex Alimentarius Commission : Guidelines on formulated supplementary foods for older infants and young children. In., vol. CAC/GL 08-1991; 1991.

13. Zlotkin, St., Siekmann, J., Lartey, A., Yang, Zh. (2010), The role of the Codex Alimentarius process in support of new products to enhance the nutritional health of infants and young children, Food and Nutrition Bulletin, Massachusetts, Vol. 31, No. 2, p. 129133.

Стаття надійшла 18.02.2019. 